IRSH 46 (200I), Supplement, pp. I07-I 29 DOI: I0.1017/S002085900I000347

(C) 200 I Internationaal Instituut voor Sociale Geschiedenis

\title{
Revolt, Testimony, Petition: Artisanal Protests in Colonial Andhra*
}

\author{
POTUKUCHI SWARNALATHA
}

This paper examines the form, content, and role of petitions in the context of protests occasioned by the handloom weavers of colonial Andhra, particularly the northern districts of the northern Coromandel region, between 1770 and I $820 .{ }^{\mathrm{I}}$ Minor and major protests and revolts by weavers erupted with increasing frequency from around the middle of the eighteenth century, whenever their socioeconomic structures and conditions of work and trade were under threat from the old and new elites, as well as from the commercial interests of the colonial state. On these occasions, weavers expressed their grievances through petitions and representations, either in combination with other strategies or independently. These petitions therefore offer opportunities to study and identify the economic and social conditions that prompted weavers to resort to collective action. Careful analyses of the petitions yield considerable insights with respect to the causes of the protests; their spatial and social diffusion; the social profile of contending parties, and their mentalities; the changing organizational structure of the textile industry; the petitions' consequences; and, finally, the attitude of the colonial state towards these petitions.

The existing literature on law and society in colonial India discusses extensively the impact of colonialism on agrarian relations and social reform issues. ${ }^{2}$ However, with a few exceptions, the implications of law and the impact of new legal provisions on the nonagrarian economy

\footnotetext{
* This article is based on material collected while working on a Ph.D. dissertation at the University of Hyderabad. I wish to thank the staff of the Andhra Pradesh State Archives and Tamil Nadu State Archives for assistance. Some of the arguments are presented in the author's forthcoming work, World of the Weaver in the Northern Coromandel: 1750-I850 (Hyderabad, forthcoming). The assistance and advice of D. Parthasarathy in the preparation of this manuscript is gratefully acknowledged.

I. The northern, predominantly Telugu-speaking districts of the Madras Presidency in colonial India constituted the Andhra region.

2. David Washbrook, "Law, State and Agrarian Society in Colonial India", Modern Asian Studies, Is (1981), pp. 649-721; Janaki Nair, Women and Law in Colonial India: A Social History (New Delhi, 1996) and Sudhir Chandra, The Enslaved Daughters: Colonialism, Law and Women's Rights (Delhi, 1998).
} 
remains unexplored. ${ }^{3}$ Here, therefore, the emphasis is on those factors that compelled the weavers to accept the "petition" as the ventilator of grievances by the beginning of the nineteenth century. In this process, it is intended to outline the way in which the art of writing and presenting petitions evolved, and how it turned out to be a crucial determinant for the success of weavers' revolts and movements.

Four major "disturbances" or "revolts" are examined that took place in the textile world of the Godavari and Visakhapatnam districts between I 775 and I 820 - the weavers' revolts of I 775 and I 798 in Godavari district, and revolts of 1796 and 1816 in Visakhapatnam district. Prior to the acquisition of political authority by the British, there was intense competition among the major European trading companies - English, Dutch and French - for control of the textile trade from these districts. ${ }^{4}$ Principal merchants, head weavers, copdars, and senapaties were the main intermediary groups with whose assistance European trading companies conducted their trading operations. 5 Except for merchants, the remaining three mainly belonged to the major weaving communities of the region. In these two districts the principal weaving communities included the Devangas, Padmasales, Pattusales and Kaikalavallu castes. ${ }^{6}$ However, more than caste, it was product specialization that constituted the major divisions among the weavers during the period, namely between fine cloth and punjum cloth weavers. Textiles that were manufactured and traded in the region included white piece goods, long cloth of various denominations, popularly called punjum cloth, and salempores, ranging from superfine quality to ordinary coarse varieties.7 Around the 1760 s, the demand for coarse varieties gradually increased in European markets, compelling the English East India Company to import these varieties. By the end of the eighteenth century, with the virtual decline in demand for

3. See for instance, Hameeda Hossain, The Company Weavers of Bengal: The East India Company and Organization of Textile Production in Bengal: 1750-I813 (New Delhi, 1987).

4. Tapan Ray Chaudhuri, Jan Company in Coromandel, 1605-1690: A Study in Interrelations of European Commerce and Traditional Economies (The Hague, I962); S. Arasaratnam, Merchants, Weavers and Commerce on the Coromandel Coast, 1650-1740 (Delhi, 1987); Sanjay Subrahmanyam, "Rural Industry and Commercial Agriculture in Late Seventeenth Century South Eastern India", Past and Present, I 26 (1990), pp. 76- I I 4; and Sanjay Subrahmanyam, The Political Economy of Commerce in South India: 1500-1600, (Cambridge, 1990).

5. The head weavers were the principal and prosperous weavers, and in some areas they were called senapaties (literally heads of armies); the copdars were essentially brokers between the merchant and the weaver and were also contractors for supplying long cloth.

6. D.F. Carmichael, A Manual of the district of Vizagapatnam in the Presidency of Madras (Madras, I869), p. 65; and F.R. Hemingway, Madras District Gazetteer: Godavari (Madras, 1907), pp. 102-104.

7. Punjum cloth was the local name for long cloth. It refers to plain white long cloth, popular in Europe on account of its length of about 37 yards or 72 cubits and width of 2 I $/ 4$ cubits; punjum literally denotes $\mathrm{I} 20$ threads. 
superfine and fine cloth, all the weavers working for the Company were categorized as weavers producing long cloth and salempores. ${ }^{8}$

The English acquired political control over the region in 1766 , and, using its political leverages, the incipient colonial state attempted to extend its control over the production process of the textile economy. 9 These changes occurred during a significant period when the textile trade reached both its peak and ebb. ${ }^{10}$ Its effects were felt in the form of the elimination of merchant groups in the organization of the production process, reinforcing community and caste linkages. They also resulted in the elimination of precolonial patron-client relations between landed elites and weavers at one level and between merchants and weavers at another level, the creation of administrative units of weaving villages, and the creation of legal institutions to enforce major bonds between the weaver and the state. ${ }^{11}$ In due course, the objective conditions created by the emergent colonial state reinforced and reproduced social categories which opposed as well as accepted the changes, depending on the benefits they derived from these transformations. Each of the changes initiated by the colonial state alarmed the weaving community, and thereby impelled them to organize protests on a continuous basis. An analysis of petitions that were submitted by weavers on these occasions reflects their awareness both of new possibilities in the realm of political and legal action and the possible outcome of their collective action.

During the mid-eighteenth century, weavers used petitions along with other weapons: foot dragging, desertion, and relocation. In these instances, "testimony" - giving oral reports of their problems to committees constituted by the Company - was popular. By the last decade of the eighteenth century, when revolts turned violent and organized protests for the redressal of grievances became the norm, the colonial state began to accept and consider petitions as the sole legitimate action to be taken by the weavers. With the introduction of new juridical systems and legal provisions by $\mathrm{I799}$, weavers were constrained to utilize the petition as the

8. The term salempores is derived from salembarigudda, the local name whose usual dimensions were a length of 16 yards and width of one yard, and the quality of which varied between an ordinary variety of $\mathrm{I} 2 \frac{1}{2}$ punjum to superfine quality of 36 punjum cloth. Salempores were mainly used for block printing in England.

9. The region of Northern Circars, which the Company acquired through the Mughal grant in 1765, was confirmed by a treaty with the Nizam of Hyderabad in 1766. Sarojini Regani, NizamBritish relations, $1724-1857$ (New Delhi, I988), provides a detailed account of this.

I०. The demand for textiles from Andhra region, chay goods (coloured varieties) from Masulipatnam, and white piece goods (salempores and long cloth) from the Injeram, Maddepollem, and Visakhapatnam factory areas reached a peak during the last decades of the eighteenth century, but started declining continuously between I810 and I830, when the factories were finally abolished.

I I. For more details on these changes see the author's forthcoming work, World of the Weaver. 
only method that had a cognizant position under the law. Petitions draw attention to the colonial juridical structure and the mechanisms that were put in place to discipline the so-called "fugitive", or "rebel" weavers and to bring them into accord with colonial structures.

\section{WEAVERS’ REVOLTS IN I 775 , I 796 AND I 798}

Soon after acquiring political authority in the region, the colonial state was much perturbed by a major revolt in 1775 by the punjum cloth weavers under the jurisdiction of the Visakhapatnam, Injeram, and Maddepollem factories. ${ }^{12}$ Changes initiated in the production organization of the textile economy were essentially responsible for this revolt. In order to ensure greater concern among weavers for the Company's investment, Anthony Sadleir, the Commercial Resident of the Injeram factory, initiated changes in production organization in $1774 .{ }^{13}$ Until then, three main European trading companies - English, Dutch and French - were operating in the trading arena of the textile economy of the region through the mediation of principal merchants, under whose charge the primary producer, the weaver, was working. ${ }^{14}$ Among the changes, the first was to place all the weaving villages falling under the jurisdiction of the Visakhapatnam, Maddepollem, and Injeram factories under the management of newlycreated administrative units called mootabs which were managed by native agencies - namely gumastabs, kanakupillais, and head weavers. ${ }^{\text {Is }}$ In this process, the informal networks, in which merchants were mediating between the weavers and the market, were replaced by a formal mechanism involving administrative intervention. Thus the role of merchants was suddenly diminished.

Secondly, with the ever-increasing demand for coarser textile varieties in Europe, weavers weaving superfine, fine and middling varieties were forced to weave coarser cloth - namely i 8-, I6- and I4-punjum varieties thus reducing their skill and specialization. ${ }^{16}$ Further, the sorting out

I 2. Until 1774 , major sections of weavers were producing fine cloth. The revolt of 1775 was organized by those weavers who were made to weave coarse cloth - the punjum cloth weavers. A section of fine-cloth weavers, who still continued to weave fine cloth, were called upon by the state to be a witness to the proceedings.

I 3. Proceedings of the Enquiry into the conduct of Sadleir, while Resident at Injeram, 28 November 1775 to 30 March I 776, Public Department Sundries [hereafter PDS] 25, Tamil Nadu State Archives, Madras, vols $24 \mathrm{~A}$ and $24 \mathrm{~B}$.

I4. Ibid., PDS $24 \mathrm{~A}$, pp. II I-I I 5 .

I 5. Ibid., PDS 24 A, pp. 70. Proceedings related to Enquiry into Conduct of Sadleir, PDS 24 A, p. 70. Concoply or kanakupillai were native accountants in charge of various functions at the factories. The types of concoplys included beating concoply, washing concoply, and sorting concoply.

I6. Testimonies given by the head weavers of Peddapuram, Amalapuram, Hasanallybadah, Arrivatum, Dungalooroo, Rustumbadah, PDS 24 A, pp. I2-I 5 . 
method was introduced, mainly to ensure a regular supply of quality fabric. ${ }^{17}$ Under this method, each specific variety was sorted into four types based on quality. The cloth that was categorized as the third and fourth quality was rejected. The cloth that was rejected was not returned to the weaver but was taken by the officials, both foreign and native, for their private trading. It is evident from the data presented in Table I overleaf, that while weavers found it profitable to work and produce punjum cloth if the pieces were accepted in the first sort, prices offered for rejected cloth did not even cover the cost of production. Thus restrictions on the quality of a specific variety led to severe constraints on the work and economic opportunities of the weavers. Moreover, weavers were forced to accept advances, and were later on ordered not to weave fine cloth for any merchant, foreign or native. ${ }^{18}$ Under the new system of advances introduced by the Company, the earlier reliance on local merchants for investment operations ceased, and after 1765 the involvement of merchants was deliberately reduced by Company officials. This was done through the mootah system, by which the weaving villages came under the management of a hierarchy of Company officials who actually managed all advances of cash and the account of cloth received from common weavers. Gradually, however, the Company brought back the copdar as an intermediary to fulfil the weavers' contracts with the merchants, either through direct purchase or by advancing cash on their looms. In the Visakhapatnam district, the Company functioned mainly through the copdars and head weavers, eliminating the mediation of merchants, a system that came to be known as the aumani system. By i 800 , the copdar was made completely responsible for the Company's investments and advances. A percentage of the advances went to the copdar. The new system thus placed a lot of power in the hands of the copdar, who often used it to delay payments, or force grain, cotton and other articles of merchandise on to the weavers. This was particularly so when traders from the Bania caste (the traditional trading community), took over as copdars in place of members of weaving castes. These changes led to what is frequently referred to in petitions and records as "economic severity" among the weavers, as they became indebted for huge amounts to the English Company.

Disturbed by the constraints imposed on their organization of production, weavers of the region, with support of their caste members, resorted to the various options available to them. They quit their work, did not accept new advances, and fled to nearby French and Dutch factory

17. Ibid. The term "sorting out method" refers to the inspection and sorting out of cloth submitted by weavers, according to quality. If the piece did not conform to the required standard, it was rejected and it was supposed to be returned to the weaver.

I8. Ibid. 
Table I. Cost of production and price data for various punjum varieties and sorts (in pagodas)

\begin{tabular}{|c|c|c|c|c|c|c|c|}
\hline \multirow{2}{*}{$\begin{array}{l}\text { Variety } \\
\text { (punjums) }\end{array}$} & \multirow{2}{*}{$\begin{array}{l}\text { Price of thread } \\
\text { per piece }\end{array}$} & \multirow{2}{*}{$\begin{array}{l}\text { Cooly hire per } \\
\text { weaver for } \\
\text { each piece }\end{array}$} & \multirow{2}{*}{$\begin{array}{l}\text { Total cost } \\
\text { of cloth, per } \\
\text { corge }\end{array}$} & \multicolumn{4}{|c|}{ Price for Company's cloth per corge } \\
\hline & & & & 1 sort & 2 sort & $\begin{array}{l}3 \text { sort } \\
\text { rejected }\end{array}$ & $\begin{array}{l}4 \text { sort } \\
\text { rejected }\end{array}$ \\
\hline 14 & 1.25 & 0.375 & 32.5 & 32.5 & 30.0 & 28.75 & - \\
\hline 16 & 1.375 & 0.5 & 37.5 & 37.5 & 35.0 & 33.75 & 32.5 \\
\hline 18 & 1.5 & 0.625 & 42.5 & 42.5 & 40.0 & 37.5 & 36.5 \\
\hline 22 & 2.0 & 0.812 & 56.25 & 56.25 & 53.75 & 50.0 & - \\
\hline 24 & 2.125 & 0.812 & 58.75 & 58.75 & 56.25 & 53.75 & 50.0 \\
\hline 36 & 5.5 & 3.0 & 170.0 & 170.0 & 160.0 & 140.0 & - \\
\hline
\end{tabular}

Note: One pagoda equals four rupees. A corge equals 20 pieces.

Source: Public Department Sundries, Tamil Nadu State Archives, Madras, vol. 24 A, pp. I I3-I I6. Testimonies preferred by the weavers of Hasanally badah before the committee meeting on 2 December I775, PDS 24 A, pp. 29-3I. 
areas. They also organized a samium, an association consisting of the four main weaving castes of the region, for collective action and represented their plight in the form of a petition. ${ }^{19}$

The economic impact of the new policies and structural changes on the weavers provoked in 1775 a reaction from the weavers of the area, who organized collective action through their caste networks. Such a congregation was made possible due to the efforts of head weavers, who wanted to express their grievances to the Company's officials. ${ }^{20}$ On this occasion, the Company's peons attacked 4,000 weavers of Kottapalli who assembled and prepared to go to Injeram to express their grievances. The fine-cloth weavers were further forced to accept advances to weave coarse cloth. When they stated that they did not know how to make it, "Mr Sadleir in answer told them that they must now learn it". ${ }^{21}$ Some weavers, who did not know the art of weaving coarse cloth, bought the same from other places and submitted those to gumastabs. In due course, they faced losses. To expose this sort of economic oppression, they fled to Yanam and Palakollu, the nearby Dutch and French territories. ${ }^{22}$ Given the new circumstances and the administrative structures initiated by the state, the weavers considered petitions as a major mechanism for grievance redressal, as will become clear. Weavers resorted to other methods only in the event of the failure of petitioning to yield results.

Detailed information relating to their oppression under the new system was brought out by the weavers through oral testimony, which they preferred to the enquiry committee appointed on this occasion. Though they also sent a delegation with a petition asking for redressal, it was not accepted by Anthony Sadleir on the ground that the weavers had not placed their signatures on the petition. To this the weavers forwarded a precise and effective reply, bringing out the exact nature of colonial intervention in their means of subsistence:

You are pleased to write us that we have not set down our names to the letter we wrote you. The names of all the weavers as far as Rajahmundry and Ellore, you have note down in your book. You may be induced to think that this Samium is made by one man - by one it cannot be done. We have done this for want of victuals and not to hurt your business. You will be please to introduce a method to procure us victuals as you are pleased to give us the same price as the merchant

19. Ibid.; "No. 2. The answer to the above translation", PDS 24.

20. Ibid.; also PDC i 6 B, i7 December 1776, pp. 814-81 5 .

21. Committee meeting on 4 December 1775; i 50 weavers of Amalapuram preferred their grievances to the committee; PDS $24 \mathrm{~A}, \mathrm{p} .46$.

22. Committee 9 December 1775 , Rustumbadah weavers' testimony, PDS 24 A, pp. I06-i io; also testimony given by Appagunta Veeresha, head weaver of Peddapatnam in front of the committee headed by Mathew Yeats. This report contains 40 testimonies given by nearly 120 weavers from 39 villages under the control of 27 mootahs; PDS 24A, pp. 43-104. 
did. Likewise you should sort our goods as they did, but if you sort them as you do and sum all our goods to lower number, how can we subsist? You write, as you will not take the notice of our petition. We are like your children, you are like our parents. If you will not have our petition, who then will? Remove our hunger and support us. ${ }^{23}$

Besides disclosing clearly the hardships of the weaving community, this petition also indicates that the weavers, though not having a mastery over written English, had yet mastered the art of petitioning, realizing that posing as humble supplicants is a necessary aspect of petitioning. The primary concern of the weavers was to obtain and sustain ways to maintain their livelihood, and so they were at pains to state that their movement was not intended to hurt the Company's investment. The petition also indicates the loss of the patron-client relationship that had existed between artisans and the state in the precolonial period.

When the weavers declined to accept any advance towards the Company's investment, a committee was appointed to inquire into the conduct of Anthony Sadleir as Commercial Resident of the Injeram Factory. The list of witnesses in the committee proceedings included commercial officers of Maddepollem, Cuddalore, and Masulipatnam, military officials, native officials, dubashes, linguists, all the gumastabs, head weavers, fine-cloth weavers, and concoplys belonging to the two factories as well as all the Company's old servants. ${ }^{24}$

In the course of the inquiry, the efforts of Sadleir to bribe the witnesses into silencewere revealed. When the investigation committee was recording the witnesses' statements, weavers from different mootabs used petitions to place before the committee the daily conduct of the corrupt officials - both foreign and native. ${ }^{25}$ Dubashes and merchants testified that they did not buy superfine cloth without Sadleir's permission. In the course of the committee's investigation, the voices of the weavers, and their collective account of their grievances, turned out to be effective. The committee, and later on the Council of the Board of Trade, passed a resolution to the effect that Mr Anthony Sadleir's management of the investment at Injeram was injurious to the Company: "(Sadleir was) cruel and oppressive towards the weavers and unwarrantable towards the agents of the French and Dutch. Resolved for these reasons that Mr Sadleir do

23. "No. 2. The answer to the above translation", PDS 24.

24. Proceedings of the committee to inquire into the complaints against Anthony Sadleir, Resident, Injeram, PDS $24 \mathrm{~A}$; William Hamilton to Committee, 27 November 1775; a list of witnesses is enclosed with this letter, pp. I I-I2.

25. William Hamilton's letter to the committee, 17 January 1776 , briefing the summary of a letter; petition given by eighteen weavers of Penumallem; a list of the weavers is provided in PDS 24 A. 
stand suspended from the Company's service until judgement of Court of Directors can be known". ${ }^{26}$

Thus, the organization of collective action by the weaving community spread over twenty-seven mootahs clearly demonstrated the possibilities inherent in political action. From inception, whether it was by sending verbal messages, petitions, organization of the samium or taking to flight, the mechanisms for their movement were clearly thought out. When the committee asked the weavers to present their grievances at Nalapalli, near Injeram, a huge gathering collected in the place. From each mootab a contingent of weavers, in certain cases as large as I 50 members, went to Nelapalli to place their grievances before the investigation committee. Seventeen to eighteen hundred weavers represented their problems in person. From each of the twenty-seven mootahs, six common weavers represented their grievances along with head weavers, gumastabs, concoplys and peons. Weavers belonging to thirty-seven villages gave nearly fifty-five testimonies. ${ }^{27}$ Unlike later revolts, which were mostly led by specific castes, this particular revolt represents the collective action of the entire weaving community, with participation from all the weaving castes and others involved in the textile industry and trade.

A more serious "revolt/insurrection" took place among the weavers of the Visakhapatnam district in I796. This was against the influence of Chinnum Jaggapah (a Bania caste copdar) over the production process, the low prices offered by the merchants for the punjum cloth, and the imposition of the salempore variety, which was opposed strongly. ${ }^{28}$ In I795, Company officials introduced some changes to ensure the quality of cloth. Earlier, the weavers were accustomed to follow a system through which they got a certain price for their cloth (I 8- and I4-punjum), and the contractor met losses incurred on account of inferior quality. Under the new system, the Resident of the factory issued notes specifying the number (representing the quality of the cloth) at which the cloth is to be received with the prices the contractor had to deliver for it. ${ }^{29}$ Strict enforcement of

26. PDS ir6 B, i7 December I776, p. 8I-86.

27. The price of thread and weavers coolie (hire) as for second and third sort of cloth is the same as first sort. Committee meeting on 4 December 1775; i 50 weavers of Amalapuram presented and testified to the same effect; PDS $24 \mathrm{~A}, \mathrm{p} .46$. The list of witnesses, total number of weavers, head weavers, gumastahs, concoplys, peons, and common weavers present from twenty-seven mootabs to prefer their testimonies to the committee; PDS 24 A, p. I80-189.

28. W. Brown, Collector, Cassimcotah, to Robert Malcolm, Commercial Resident [hereafter CR], Visakhapatnam, 24 July 1796; Board of Revenue (Proper), [hereafter BORP], Tamil Nadu State Archives, I62, pp. 8058-8068.

29. Robert Malcolm, CR, to Mr Webb Coll of Northern Division of the Visakhapatnam, 27 July 1796, Visakhapatnam District Records, [hereafter VDR], Andhra Pradesh State Archives, Hyderabad, vol. 3706 , pp. 325-327. 
rules and regulations by the native agency placed greater burdens on the weavers as they had to pay extra charges. Thus, the economic hardships bound together the weavers of the district, who stopped their work for the Company and incited other villagers to join them. Such an act was made possible by the leadership provided by caste leaders belonging to the Devanga caste and other senapaties to induce the weavers to join the movement. ${ }^{30}$

Since the weavers expressed their grievance through sudden action, without bringing it to the notice of the officials, the entire incident was dubbed an "insurrection" by "fugitive" weavers. Company officials felt that the proper way to express their grievances was "to state them in person, which if possible would be redressed". The Collector stated that the weavers were still continuing their action, without yielding to any sort of appeal, "no overtures have been made on the part of the fugitive weavers, who continuing still more or less intent on their purpose of extorting, rather than petitioning for redressal of grievances". He further expressed the hope "they would yield to reason, and insisted on the senapaties of the several parties to represent their story in a quiet submissive manner". ${ }^{3 \mathrm{I}}$

In I798, weavers of the Godavari district "revolted" against major changes initiated by the state in its investment policies. Grievances came to the fore, such as inadequate prices for their work, particularly when there was an acute scarcity of thread, and a new policy of the Company to collect balances due from the weavers at the time as advances made during the early part of the year. However, the immediate cause of this revolt seems to have been the harsh treatment meted out to Company weavers by Company merchants, who began collecting balances due from the weavers with much rigour. ${ }^{32}$ Nearly i 5,000 pagodas was owed to the merchants, who were advised by Richard Dillon, the Commercial Resident of the Maddepollem factory, to collect from the weavers according to their economic circumstances. The merchants decided to collect one rupee monthly from better-off weavers, half a rupee from poorer weavers and one-quarter rupee from the poorest. Secondly, weavers did not want to confine their contracts to one merchant to whom the Company provided advances. They wanted the right to be granted to any merchant to make advances both on Company looms and on private looms. The Commercial Resident expressed his inability to take any measures, and requested that a

30. BORP i62, pp. $8063-8074$.

3I. John Snow, Collector, Cassimcotah, to Robert Malcolm, CR, Vizianagaram, 26 July i776; VDR 3706, pp. 330-332.

32. Richard Dillon, CR, Maddepollem to William Fallofield, Board of Trade [hereafter BOT], Godavari District Records, [hereafter GDR] 830, Andhra Pradesh State Archives, pp. 19-46. 
few from their caste represent their grievances in the form of a petition to the Madras government. ${ }^{33}$

Changes in the structures, whereby Bania-caste copdars assumed a significant position in the textile trade, provided a common platform for the head weavers, caste leaders (senapaties) and common weavers to air their grievances. Head weavers, and senapaties in particular, played a crucial role in this particular disturbance, led by head weavers belonging to all four major weaving castes of the region. Soon after the revolt's inception, the Collector recommended that these "tumultuous assemblies should disperse, leaving behind them ten head weavers comprising all four major weaving castes, with one weaver from each important weaving village. After hearing their grievances, he would recommend to redress them". ${ }^{44}$ Weavers opposed this suggestion and continued their movement, bringing weavers from various villages into the fold. Weavers moved from one village to another and, with the support of their principal and head weavers, strictly refused to undertake Company's work. From Daglooroo village in Godavari district, they marched towards Masulipatnam, bringing under their banner the weavers of all the villages situated on the route. ${ }^{35}$

The Board of Trade took serious note of this crisis, as the merchants working for the Maddepollem factory refused to enter into contract for the year owing to the disturbances. In such a situation, the official perceptions regarding the weavers' movement, and its ability to express problems in a written complaint, instead of causing a better result appears to have resulted in further apprehension in the colonial mind. The concern of the authorities about the troubles, and their surprise at the tumult caused by weavers and their organizational capacity was made obvious when the officials stated,

$[\ldots]$ by what means people so miserably poor as weavers are generally known to be, could now contrive to keep so long together [...]. The original copy of a representation sent to [...] appears to be written in so masterly a style [...] that knowing the weavers as well as me, I confess that I did not imagine them capable of such a superior production. ${ }^{36}$

Weavers who had decided on "insurrection" appear to have sent a

33. Richard Dillon, CR, Maddepollem to Benjamin Branfill, Collector, 8 January I798, GDR 847 , pp. I 4 I-I 42 .

34. Richard Dillon, CR, Maddepollem to William Fallofield, BOT, GDR 830, p. 32.

35. The "insurrection" disturbed the state of affairs in the Ist, 2nd, and 3 rd Divisions of Masulipatnam and thereby affected investments at the Maddepollem factory; 300 weavers gathered in the village of Daglooroo in the mootah of Chintapurroo in the 2nd division under the leadership of two head weavers - went to Relingy and their number rose to 500; they then proceeded to Yellindeperma in the Nidadavole Parganah of the 3 rd division.

36. Richard Dillon, Maddepollem Factory to William Fallowfield, BOT, Madras, I9 January I798; GDR, 830, pp. 19-23. 
representation to the authorities specifying the economic grievances that forced them to act on this occasion. This particular revolt is also significant from the viewpoint of state action. The state, instead of insisting upon them resubmitting their cases peacefully, as had happened in the case of the I796 revolt in Visakhapatnam, tried all methods to put down the revolt. In this case, this problem was further complicated when the weavers cut across the existing revenue districts and tried to bring other weavers under their control. Consequently, the officials were left with no policy measure to deal with such a situation, which caused confusion and rifts between the revenue and commercial interests of the districts.

As a result of these disturbances to the production process, the Company considered many changes in the weaving world of the region during the late $\mathrm{I} 790 \mathrm{O}$, to protect its investment. Eliminating the merchants and according official recognition to copdars of the weaving caste - the main agents in the commercial activity - were some of the changes that were adopted, along with the more powerful judicial regulations.

In the early nineteenth century, under the impact of these changes, the only mechanism left to weavers to express their grievances was through legal procedures, without which their grievances were not attended to by the state. The idea of putting in place legal mechanisms was first adopted in 1794, when the Company noticed the unprotected nature of manufacture in its jurisdiction as the District Collectors were not able to act, due to the nonavailability of any kind of guidelines. The Board of Trade considered the importance of applying a set of judicial regulations similar to the ones that were already in existence in Bengal. The issue came up before the Board of Trade again in 1799, when it decided to adopt regulations for the conduct of Commercial Residents and agents, and all persons employed or concerned in the Company investment, along with changes at the level of production organization. ${ }^{37}$

The regulations adopted concerning weavers were, in general, "sufficiently severe".$^{8}$ They were prohibited from working for individual Europeans or native agencies or for bazaar sales until they would complete their engagements in relation to the investment they had agreed upon. "Peons may be placed over such as fail in their engagements mainly to ensure a quick delivery"; in case of any deficiency and incurring of losses the weavers were made to clear the debts they owed to the Company in preference to the claims of any others. All contracts with weavers were to be made in writing, in the presence of at least two credible witnesses; weavers were asked to give fifteen days advance notice if they decided not to take any more advances. Further, if the weaver acted in a way

37. Boards Proceedings on the Introduction of the Judicial and Revenue System of Bengal, Board of Revenue Miscellaneous, 190, G.No.18288, Tamil Nadu State Archives, pp. 316-319. 38. Ibid. 
contradictory to these stipulated rules and regulation, he was liable to be prosecuted in the Court of Adawlat.

These new legal procedures initiated by the colonial state were intended to put an end to sudden protests. "Disturbances" and weavers' "unwarranted" actions were no longer to be tolerated by the state. Weavers were provided with a new mechanism to put forward their grievances to the state, namely the petition. Only in certain circumstances were the weavers given a chance to sue the officials or persons concerned in court. One of the clauses of the new regulation that enabled them to sue the Commercial Residents, and their native officers of any category, in the Court of Adawlat specified the following grounds. First, when a proper and agreed price was not paid for the cloths they submitted; second, when their accounts were not settled on fair terms; and third, when they were forced to pay unjust fines on account of peons placed over them. However, the aggrieved party, the weaver, had to prefer the complaint to the Commercial Resident, and only if that complaint was not redressed within a reasonable time could the weaver sue the Resident. ${ }^{39}$

A petition to the authorities was thus the only means left to the weavers of the region to get any relief against oppression that was directly related to the activities of the Company's investment operations. However, under the new judicial regulations, the state restricted the weavers' actions to economic grievances, and further, grievances that could be petitioned were clearly specified along with a procedural hierarchy for preferring complaints.

Hence, the weavers started using petitions very judiciously and cautiously, more so in cases against the Company's officials. When they filed a petition, they included every minute detail about the activities of all those connected with the Company's investment in the region. One such occasion during which weavers of the Visakhapatnam district depended entirely on the use of petitions was the i 8 I6 Revolt.

\section{THE VISAKHAPATNAM REVOLT OF I 8 i 6}

The Company's investment received a great setback in I8 16 when nearly 20,000 weavers in the Visakhapatnam district stopped their work and assembled at the Simhachellam Hill Temple near Visakhapatnam. Since congregations were forbidden under the new law, their main purpose for such a gathering was "to attract the attention of higher authorities" to the severe oppression put on them by the native agency, with the support of 
the Commercial Resident of the Factory. ${ }^{40}$ Petitions submitted by weavers to the Board of Trade throw light on the economic history of the weaving community. At the organizational level, issues such as individual- as well as community-level consciousness, individual leadership, and temporal and spatial aspects of writing a petition, can be analysed from these "humble" petitions. ${ }^{{ }^{\mathrm{I}} \mathrm{T}}$ The form and tone of petitions submitted during the revolt of I 8 I 6 show that the weavers had come to terms with the new rules and regulations of the colonial state, and were trying to retain their place within the new economic system by reference to their "humble" stature in relation to the Company and the state. The need for a trained person to be employed in the writing of such petitions - one who had mastered the new legal terminology and procedures - was understood, and indeed weavers managed to find such persons.

This particular revolt appears to have been caused by the overall unhappiness of the weaving community with a few powerful persons who were not giving due consideration to the changes in work organization brought about the Company. Perhaps because of this, the weavers recognized the necessity of using petitions as the only way to resolve long-standing grievances. Through their petition dated i9 March I8I7, twenty-eight weavers, acting as agents to the Company's weavers in Visakhapatnam district, went to Madras and requested the Board of Trade to place their petition before the Governor-in-Council.42

It constituted an account of the economic severity which the weavers of the district suffered at the hands of Chinnum Jaggapah, the Head Servant of the Company since I 8 I I. In that year Chinnum Jaggapah, a Bania, was appointed as head servant or copdar of the factories by the Commercial Resident, Henry Taylor, and his relatives were placed in charge of a number of looms under their control. From each and every copdar of the district, Jaggapah extracted half a rupee per loom whenever advances were made. Every year, he was collecting the pay of those peons who were employed to guard his house at the time of "disturbances". Moreover, whenever the weavers attempted to obtain justice from the Commercial Resident, they were severely ill-treated. Unable to get justice from the immediate authority, they assembled at Simhachalam temple in Visakhapatnam district. ${ }^{43}$

40. The Humble Petition of the Head Weavers and Weavers employed in Company's punjum Cloth investment in the Vizagpatnam Zillah, presented by the undersigned Agents to the Whole Body, to Hugh Elliot, Governor in Council \& Others, Fort St. George, Commercial Department Consultation, [hereafter CDC] io, Tamil Nadu State Archives, Madras, dated i9 March i8 17, pp. I $249-\mathrm{I} 257$.

4I. This represents one of the first instances when the term "humble" was used by the weavers in a petition.

42. Ibid.

43. Ibid. 
The nature of complaints made by the weavers against the copdars shows very clearly the actual history of the weaving trade in Vizagapatnam during the late eighteenth century and early nineteenth century. In their first petition of 29 November I 8 I6, they explained the rates established by the government, which were paid to the copdars by the Company for its investment. Earlier, they were getting Company-established prices but since I 8 I I lower prices were being paid to them. ${ }^{44}$

Once cloth was rejected and returned to the copdars, they collected Rs. 3 to Rs. 20 for each piece of I 8- and I 4-punjum cloth that was rejected. The weavers thus incurred a heavy loss when the rejected cloth was not returned to them, but was sold by the copdars to private merchants at an higher price. Soon after the Company disbursed advances to the copdars, the latter usually lent the money to the soucar (merchants) and zamindars (tax farmers) for interest. They got back the money from the soucars both in grain and money, the former being supplied at a cheap rate. This grain was forced upon the weavers at high prices. ${ }^{45}$ Weavers were thus paid in cash and grain, even though in the account books the full price was mentioned.

On this occasion, to their surprise, the weavers noticed that the Commercial Resident was supporting the cause of his dubash Chinnum Jaggapah and his relative copdars - Grundy Vencataramoodoo and Motamurry Paupiah. They therefore sent their agents to Madras to represent their case before the Presidency. ${ }^{46}$ They demanded a new Resident for Visakhapatnam to investigate and redress their grievances, and wanted the amount that had been held back since i 8 I I by the copdars, on account of the punjum cloth, to be paid to them. On this occasion the petition was seen not only as an instrument by which the weavers brought their miseries to the notice of government, but as a weapon to make known what they wished to achieve. 47

The weavers then sent a second petition to the Board of Trade, dated I 3 December I8I6, which sought to place before the Board the daily illtreatment that they had to face. When Henry Taylor, Chinnum Jaggapah, and other copdars came to know of this petition, they went to their macaums, and with the help of I 30 pariah peons, placed in confinement all

44. Petition of the weavers' agents to the body of Company's punjum gents to the body of Company's punjum cloth weavers, to Board of Trade [hereafter BOT] 29 November I 8 I 6; CDC Io, pp. I257-I263. Also translation of a petition from Emenda Jagapa, Davoleree Romoodoo, Emunda Mulliah, weavers of Coderee Macaum in the district of Visakhapatnam, to the Magistrate, 30 July i 816; CDC io, pp. I 264-1 268.

45. In this petition, the weavers brought out the deterioration in the economic conditions of their community due to the low price offered for their cloth by Henry Taylor, since the time Chinnum Jaggapah was reinstated in I8I; petition dated I9 March I817 to BOT, CDC I0, pp. I $249-$ I 257 .

46. Ibid., p. I25 I.

47. Ibid., pp. I $25 \mathrm{I}-\mathrm{I} 252$. 
those weavers pointed out by Chinnum Jaggapah and other copdars. They forced these weavers to give sunneds (deeds or agreements) to testify to information opposing the weavers' problems addressed to the agents in Madras. ${ }^{4}$ The copdars sought this kind of information and documents from those weavers who were poor. Those who refused to give such information were forced to discharge their balances demanded by the copdars. The weavers then suggested that they would pay for all the charges incurred for investigation, and would accept any punishment, if the charges against those copdars "were not proved through investigation". ${ }^{49}$ This petition shows the limitations of petitions as a historical source, and the need to be careful in using these sources, for petitions can also be falsified accounts, as some weavers were brought forcibly by the copdars to sign the papers. ${ }^{\circ}$

When their ill-treatment intensified by the day, the weavers sent yet another petition, dated 2 February I 8 I7, this time by Tappal to the Board of Trade, which placed before the highest authority the intensity of illtreatment meted out to them by the copdars. ${ }^{\text {I }}$ This particular petition is useful in that the weavers, while describing the situation under the jurisdiction of a factory, also reveal the history of an individual Chinnum Jaggapah - who rose to an important position in his locality owing to the unlimited favours bestowed on him by Company officials. It also brought to the fore the issue of corruption and bribery that rapaciously engulfed the commercial affairs of the Company. Jaggapah was removed once from the Company's service, but returned to the same position with more powers due to his "crafty nature". He concocted false evidence before the court of Adawlat and refuted all the allegations against him. ${ }^{52}$ Jaggapah was also responsible for the removal of previous copdars from the Company's service, and he placed all these macaums under the leadership of his relatives - his own brother-in-law and the father-in-law of his brother, along with other Banias and Devangas of his liking. Most of the servants in the Company's service were appointed according to his choice. During Henry Taylor's tenure, Jaggapah rose from a servant employed on a salary of I 4 rupees per month to the man with full control over factory affairs, who carried on extensive trade, and "purchased landed property and vessels".

\footnotetext{
48. Ibid., p. I25 I.

49. Ibid., pp. I249-I256. Petition of the weavers' agent to the Body of the Company's punjum cloth weavers in the district of Vizagapatnam, to BOT, I6 December i 8 I6; CDC I0, pp. I264I273; petition dated 29 November I 816 to BO; CDC io, pp. I257-I264.

50. Ibid.

5I. Reference to this petition is provided in CDC го. Tappal is a system of post wherein articles and letters are transported through a relay system.

52. Weavers' petition to BOT dated 29 November I8 16; CDC io, pp. I257-I 264.
} 
Based on the information provided in these petitions, the Board summarized the entire issue as follows and gave appropriate instructions for redressal. (a) Ill-treatment of certain weavers by persons connected with the factory at Visakhapatnam, and complaints related to this weavers (petitioners) were ordered to prefer their complaints to the Magistrate in the Zillah. (b) Payment of just dues withheld by the copdars - petitioners were asked to complain to the Resident in the first instance for the recovery of the dues, and if not satisfactorily decided by the Resident, to appeal then to the Zillah court. (c) The influence of the native agency on the public establishment who were the leading cause of promoting the irregularities - petitioners' agents were ordered to appear before the Resident to enable him to investigate the charges against the servants of the factory, viz. Chinnum Jaggapah, and other copdars. 53

The weavers, however, expressed their inability to accept the three Board of Trade orders on two grounds. The first was:

It is notoriously known in this part of the country that the weaver class is the most ignorant and meekest part of the community. Consequently, your petitioners can never dare to complain to the magistrate against the Resident for the ill treatment the weavers at various times unjustly and undeservedly received from that office.

In relation to the second article of the order, the weavers stated that it was not possible to prefer their complaints to the Resident. To offer individual complaints was impracticable as they were "very poor, illiterate and ignorant, and to recover such a huge amount from the copdars they had to starve themselves, and put their families to death, as the daily work was the only source of sustenance for them". ${ }^{4}$ Moreover, they felt that this process would affect the Company's investment. Therefore, the petitioners accepted only the third order of the Board of Trade.

The response of the petitioners to the orders of the Board of Trade shows an awareness of legal mechanisms and the appropriate methods of dealing with Company officials, and shows the overall clarity with which they carried out their "movement". It also demonstrated the contradictory images they projected about themselves. They considered themselves as the "meekest and ignorant elements of the community", who had no strength to prefer their complaints in the district court. Further, they stated that they were too "poor, illiterate and ignorant" even to pursue their complaints related to the recovery of dues. Before the colonial state, they considered themselves as weak elements, a strange situation when compared to the late eighteenth century. For instance, in 1796 they were

53. Ibid.

54. Weavers' petition to BOT dated I6 December I8 16; CDC ıо, pp. I269-I273; weavers' petition to BOT dated 2 February I 817; CDC 10, pp. I273-I 277. 
objecting to even a slight change in the organization of the production process and were considered by the colonial state as fugitive, rebellious and barbarous. From a situation where they perceived the Company as being intrusive in their economic activity, the weavers had reached a stage where they saw the Company as, in fact, being of assistance in expanding economic opportunities. However, in order to protect their interests while at the same time reaping the benefits of colonial trade, they resorted to various methods of redressal of their grievances while at the same time taking care not to offend Company officials too much.

Thus the organization of the I8I6 movement indicates the strength of caste and community networks, and the weavers' strategic abilities, although they do not admit this openly, and instead portray themselves as poor, meek, and humble clients of a new patron. The weavers appear to have been meticulous in understanding the procedures relating to investigations, and therefore asked the Board of Trade to see that Chinnum Jaggapah not only be distanced from the commercial affairs of the factory, but be removed from the area of Visakhapatnam itself. Further, they stated that they would provide the necessary proofs for the grievances and charges levelled against the copdars. They said that they had not passed these to the Board of Trade out of fear that the Board would forward them to the Commercial Resident for examination, which would then result in a tampering with the proofs and other evidence by Chinnum Jaggapah. The weavers therefore reserved those complaints to be brought forward before the Enquiry Committee. 55

Thus, apart from complaining to the Board of Trade, the weavers also took pains to state the authenticity of their cause, and promised that they would pay off all the expenses incurred in connection with the conduct of the investigation and enquiry. They were only too acutely aware of the corrupt practices and mechanisms used by copdars and Company officials to shield themselves from accusations.

When the weavers were asked to send twenty representatives from their gathering at Simhachellam, these were taken to Visakhapatnam where they were confined. Upon this, the weavers thought it proper to bring to the notice of the Magistrate their situation and requested that measures be adopted to relieve the weavers from their oppression; they also asked that they might receive the Company's price for their cloth at established prices, and that the earlier balance be paid back, and finally that the entire advance was to be paid only in cash. ${ }^{6}$ The Magistrate's office totally rejected these demands stating:

$[\ldots]$ as the petition was not written conformably on a stamp paper, $[\ldots]$ even if

55. Petition to BOT dated i9 March i 8 i7; CDC io, p. I255.

56. Ibid., pp. I255-I 256. 
they written it was a civil complaint but not a criminal one. Moreover they had not specified the amount which for they were due. In fact as agreeable to the petition, it had to be delivered to the Adjunct Court but as it lacked regulation it is rejected totally. 57

The weavers, who had hoped for quick justice from their first petition, dated 2I November I8I6, and not receiving any redress, on becoming aware that the weavers had sent their agents to Madras, dispatched their second petition on 16 December 1816 specifying the increased harassment caused to them by Henry Taylor and Jaggapah. With the help of I 30 pariah peons whom they hired on an hourly basis, these men had forced the weavers to give false sunneds, negating whatever they had said earlier. On this action, "the petitioners further stated that if the copdars and Jaggapah had not done any evil then there was no necessity for them to employ I 30 pariah peons to make the weavers to give a certificate".

The agents presented another petition that they received to the Board of Trade, in which the weavers specified that the certificate had been obtained by compulsion and that "to save their property, houses and weaving tools from being put up for public auction, they gave such certificates". Weavers who refused to furnish certificates were forced to pay off other balances by auctioning their property. In this third petition, dated 2 February I 8 I 7 , the weavers gave an account of the illtreatment they were made to suffer and told how the copdars exacted sunneds from the weavers by compulsion and outright torture.

The weavers clearly demonstrated the oppressive character of Jaggapah and the influence he had been exerting over Henry Taylor. They expressed their regard for other commercial and revenue officials whom they compared favourably with their oppressors, by requesting of the Board of Trade,

[...] the appointment of a gentleman like Mr Thackeray, Mr Brown, or $\mathrm{Mr}$ Robinson, because the weavers thought that these people would not "mind" any rich natives or give weightage to the recommendation of any European in the administration of justice. If the board would send any one of the persons, they would come to know that it was not thousands but lakhs [hundred thousands] of rupees that had been taken unjustly from the weaving community.

By not casting any aspersions on officials as a category and by differentiating between good and bad officials, they perhaps hoped to project the impression that they were not opposed to the Company and its activities per se, but were only opposing the behaviour of specific officials.

In this particular revolt therefore, the weavers dispatched a series of petitions to put pressure on the authorities to redress their grievances. The

57. Petition of the weavers agents to the Body of the Company's punjum cloth weavers in the district of Vizagapatnam, 29 November I 816; CDC ıо, pp. I257-I 264. 
officials in Madras, however, prior to initiating any plan to consider the issues, imposed a precondition that all the agents camping at Madras should return to their respective places. Written orders were issued to this effect. ${ }^{8}$ On their return, however, the weavers were abused and assaulted by the Bania copdars, and were moreover, pressurized by Henry Taylor to pay back their outstanding balances to the Company. They were also not given any fresh advances, thus severely impacting on their economic condition. In this situation, the weavers submitted a common petition with $20 \mathrm{I}$ signatures affixed.59 The text and content of this petition enable us to observe the indignation, as well as the anxiety, on the part of the weavers, when the state was delaying consideration of their grievances.

We presented many petitions praying to direct a discontinuance of the interference of the copdars [...]. We are poor people and live by earning by our labour. We therefore request you will protect us [...]. In consequence of our having made complaints we are deprived of the advances of money for weaving clothes [...]. We have suffered a great loss and how come we conduct our business if we be put under those who dislike us. We complain of our case to your Board and beg you will be pleased to appoint any gentlemen you think proper to inquire into our grievances. When Mr. Mango Dick was here and in the Board he treated us as the children of the Honourable Company and ever since his departure to Europe, Chinnum Jaggapah now of great influence and the present gentleman (Mr. Taylor) has been doing great injustice towards us and we live now as children without parents. We pray that you will be pleased to depute some gentleman to render us justice and you will we hope protect us. ${ }^{60}$

This, then, was the first time that the weavers openly displayed their feelings regarding the inordinate delay by the authorities in taking cognizance of, and acting upon, their petitions. It was also the first instance in which they attacked the Commercial Resident for his "unjust" actions.

The weavers' remarkable consciousness regarding the use of various judicial and legal mechanisms and their organizational abilities are also reflected in these petitions. Sending representatives from each macaum, ensuring proper authorization, collecting signatures from thousands of affected weavers, they ensured that their petitions were not rejected on legal or procedural grounds. It was due to this thorough and methodical process that the enquiry committee finally agreed upon, and corroborated, most of the complaints of the weavers. ${ }^{61}$ This particular revolt turned out

58. Translation of a petition from Emenda Jagapa, Davoleree Romoodoo, Emunda Mulliah, weavers of Coderee Macaum in the district of Vizagapatnam, to the Magistrate, 30 July I8 I6; CDC io, pp. I $264-$ I 268.

59. Petition of weavers' agents to BOT dated i6 December i8 16; CDC io, pp. I269-i 273.

60. Ibid.; also weavers' petition to BOT dated 29 November i 816; CDC I0, pp. I 258 - I 264.

6r. Ibid.; also petition dated I7 May 18 17; CDC ıо, pp. 565-570. 
to be a success, as the enquiry committee recommended the dismissal of Chinnum Jaggapah and other Bania copdars, and ordered that the oldestablished division of macaums under the command of a head weaver copdar should be revived. The entire management of the factory was to be placed under a committee of two members, the senior member to be in full charge of the factory, who would also (I) investigate the dismissal of weaver-caste copdars; (2) examine the minute details of the accounts of actual deliveries and advances by the weavers; (3) investigate exaction collected by the head servant of the factory; (4) examine the possibility of instituting legal proceedings against the head servant and others for recovery of money exacted; and ( 5 ) assess and investigate the accusations of personal violence committed by the copdars with the sanction of the Commercial Resident.

The committee arrived at the conclusion that "a course of fraud and plunder had been pursued for years" by native agents, in association with their European superiors, which led to undue suffering of the weavers and denial of their just dues. More important perhaps was its statement that it is necessary to find out why, despite the establishment of a judicial system, weavers chose to follow the older mechanisms of flight and assembly to get their grievances brought to the notice of the authorities, and in particular the "causes which militate against weavers having recourse to the Courts of Justice".

\section{CONCLUSION}

The social history of the weaving community, their concerted efforts and solidarity in times of crisis, comes out clearly from the weavers' revolts recounted above. Weavers used their traditional community organizations such as caste associations and samiums in the 1775 Godavari district revolt and in the I8I 6 Visakhapatnam revolt. In both these, weavers cut across caste groups in launching their movement. In contrast, in the 1796 revolt, the participants almost entirely belonged to one caste - Devangas. However, despite all the obstacles of illiteracy, lack of power, and resources, the ability of weavers to successfully obtain and maintain community support across space and time stand out.

Other than caste and community-based groups, skill-based groups also came to the fore in these revolts. On occasion, socially and economically marginalized sections tended to have lower ranks in the social hierarchy. But when it came to opposing the deskilling processes, affected weavers from different castes came together to oppose the new structural and trading arrangements. Thus, these revolts presented contradictory images. Throughout the period, weaving castes opposed interventions that affected their skills, as these would lower economic and opportunity structures. On the other hand, this very process provided greater scope 
for all the weaving castes to unite and oppose the "undue" interference in their productive and trading activities, be it from local elites, intermediaries, or government officials. Thus, while divisions based on caste, skills, and specialization were a dominant feature of the textile world prior to the establishment of the East India Company, the structural changes brought about by the Company made it possible for different groups to unite.

Another feature that is established is that both the weaving community and the state accorded importance to the petition as a mechanism for redressing grievances, and, in fact, it progressively became the dominant mode of expressing grievances. Moreover, these petitions gave voice not just to economic complaints but were also directed against social and political exploitation, as well as voicing certain incipient "human rights" issues, including the right to subsistence, freedom from physical abuse, and the right to be heard. For the state, petitioning was not only a more convenient and efficient form of considering grievances, but petitions were also the means by which state officials learned about popular feelings and discontents regarding the new policies and structural changes that were being effected. This was important since, apart from economic changes, the new systems were creating and destroying certain social categories, and transforming the organization of the production system in the region, resulting in shifts in the native power structures.

The petitions also demonstrated the perceptions of colonial officials regarding the colonized. The language and tone that is used in response to the petitions provide indications of this. Weavers are "poor and illiterate", and therefore their ability to write a petition is questioned. Their linguistic and communication skills were suspect, but also a cause for apprehension, as they posed a threat to colonial domination. Western superiority over "barbarous and uncivilized" weavers could be preserved only if they conformed to the images adopted by their colonial masters.

But perhaps the most important conclusion to emerge from an analysis of weavers' petitions is that weavers learned, over the course of time, the methods of dealing with colonial officials and the "best" methods for achieving their objectives. Initially, they took to desertion, flight, assembly, and mutiny, and publicly questioned the authority of colonial officials. Especially when their community members were displaced from leadership positions in the organization of production, and replaced by Bania caste copdars, they protested violently. However, gradually perhaps realizing the importance and benefits to be derived from colonial trade, and their structural weaknesses in the face of an increasingly powerful state, they began to resort to more peaceful and "legal" mechanisms. Therefore, the use of petitions is a mirror of structural changes taking place in early colonial Andhra - increasing subordination to colonial commercial interests and resentment against this, expanding economic opportu- 
nities, disintegration of traditional patron-client relations, and the possibility of collective action for grievance redressal rooted in legal and judicial principles, rather than being subjected to the whims of feudal patrons. 